Original Research Paper

\title{
Geometry and Determining the Positions of a Plan Transporter Manipulator
}

\author{
${ }^{1}$ Relly Victoria Virgil Petrescu, ${ }^{2}$ Raffaella Aversa, ${ }^{2}$ Antonio Apicella, \\ ${ }^{3}$ Samuel Kozaitis, ${ }^{4}$ Taher Abu-Lebdeh and ${ }^{1}$ Florian Ion Tiberiu Petrescu \\ ${ }^{1}$ ARoTMM-IFToMM, Bucharest Polytechnic University, Bucharest, (CE), Romania \\ ${ }^{2}$ Advanced Material Lab, Department of Architecture and Industrial Design, \\ Second University of Naples, 81031 Aversa (CE) Italy \\ ${ }^{3}$ Florida Institute of Technology, USA \\ ${ }^{4}$ North Carolina A and T State University, USA
}

Article history

Received: 13-12-2017

Revised: $16-12-2017$

Accepted: 27-12-2017

Corresponding Author: Florian Ion Tiberiu Petrescu ARoTMM-IFToMM, Bucharest Polytechnic University, Bucharest, (CE), Romania E-mail: scipub02@gmail.com

\begin{abstract}
The conveyor mechanism (working in a plan) to be presented in this study is a classic case of manipulating conveyor, simply with a single degree of mobility. It is a very common mechanism used in classical mechanics, being encountered at lifting platforms, at handicapped chairs, at cranes, forklifts, automatic machines and machines, or at older steam locomotives where it having the role of reversing the rotation-translation movement. Being a simple, common manipulator, he is also a good teaching example, much used in the student courses of mechanics, mechanisms, robotics-mechatronics. That is why we want to present in this study in a concise way the geometry and the kinematics of this mechanism. There will be a constructive and one kinematic scheme. The mechanism consists of a crank (a motor element 1), an RRR dyad composed of elements 2 and 3 and an RRT dyad formed by kinematic elements 4 and 5 . The motor element 1 has a complete rotation (360 degrees) being the single driving feature of the entire mechanism. The element 3 is a bar that links the engine element 1 to the rocker element 2. From the rocker element 2, the movement is forwarded through the rod 4 to the final execution member 5 , which is a slider (patina), having the role of oscillating linearly (it can also be a piston in a cylinder). The mechanism can also be used by changing the driving element to the driven one so as to become a motor mechanism with the leading element 5 and when the rotation element 1 to become a final driven element. Thus it can be used as a mechanism for producing the movement and transmitting it with the conversion from the rotation to translation movement. We intend to present this mechanism, in the present paper, when it functions as a manipulator, having the motor element 1 and the final element, the execution element, the patina 5 . Special emphasis will be placed on the kinematics of the mechanism, studied on elements, but also on structural groups. Obviously there will be presented and some applications of the mechanism.
\end{abstract}

Keywords: Mechanism, Manipulator Plan, Transporter, Motor, Dyad, Geometry, Positions, Kinematics, Transporter Mechanism, Motor Mechanism, Robots, Mechatronics, Motor Element, Execution Element, Bar Element, Patina, RRR Dyad, RRT Dyad

\section{Introduction}

Robots and manipulators are now used in all industrial fields, instead of humans, taking heavy, repetitive, tedious operations into toxic, hazardous environments in heavy-duty industrial areas where there were dangers of manipulation of objects and people. Simple conveyors or manipulators have the role of 
moving an object from one place to another. It is then processed, processed, indiscriminately and ready for manufacturing and manufacturing. Between all the main operations, it is necessary that the piece in question be handled. Manipulating robots are generally used as simple as possible, the most common being the anthropomorphic. Very simple linear handling operations can be used but simplified manipulator robots. Such mechanisms have been used since ancient times in the mechanisms of steam locomotives, having the role of transforming the linear motion into a rotation or vice versa (Fig. 1).

In Fig. 2 shows the kinematic constructive schematic of a simple conveyor mechanism with various uses, such as transforming the rotation motion into a linear motion or vice versa, manipulating an object by sequentially moving it sequentially by means of an actuator or other positioning of the parts, sequencing some moves.

In the proposed study we will limit to a simple conveyor mechanism having the kinematic scheme given in Fig. 3. Only the geometry of the proposed conveyor mechanism and its kinematics will be studied in the present paper.

The conveyor mechanism (working in a plan) to be presented in this study is a classic case of manipulating conveyor, simply with a single degree of mobility. It is a very common mechanism used in classical mechanics, being encountered at lifting platforms, at handicapped chairs, at cranes, forklifts, automatic machines and machines, or at older steam locomotives where it having the role of reversing the rotation-translation movement.

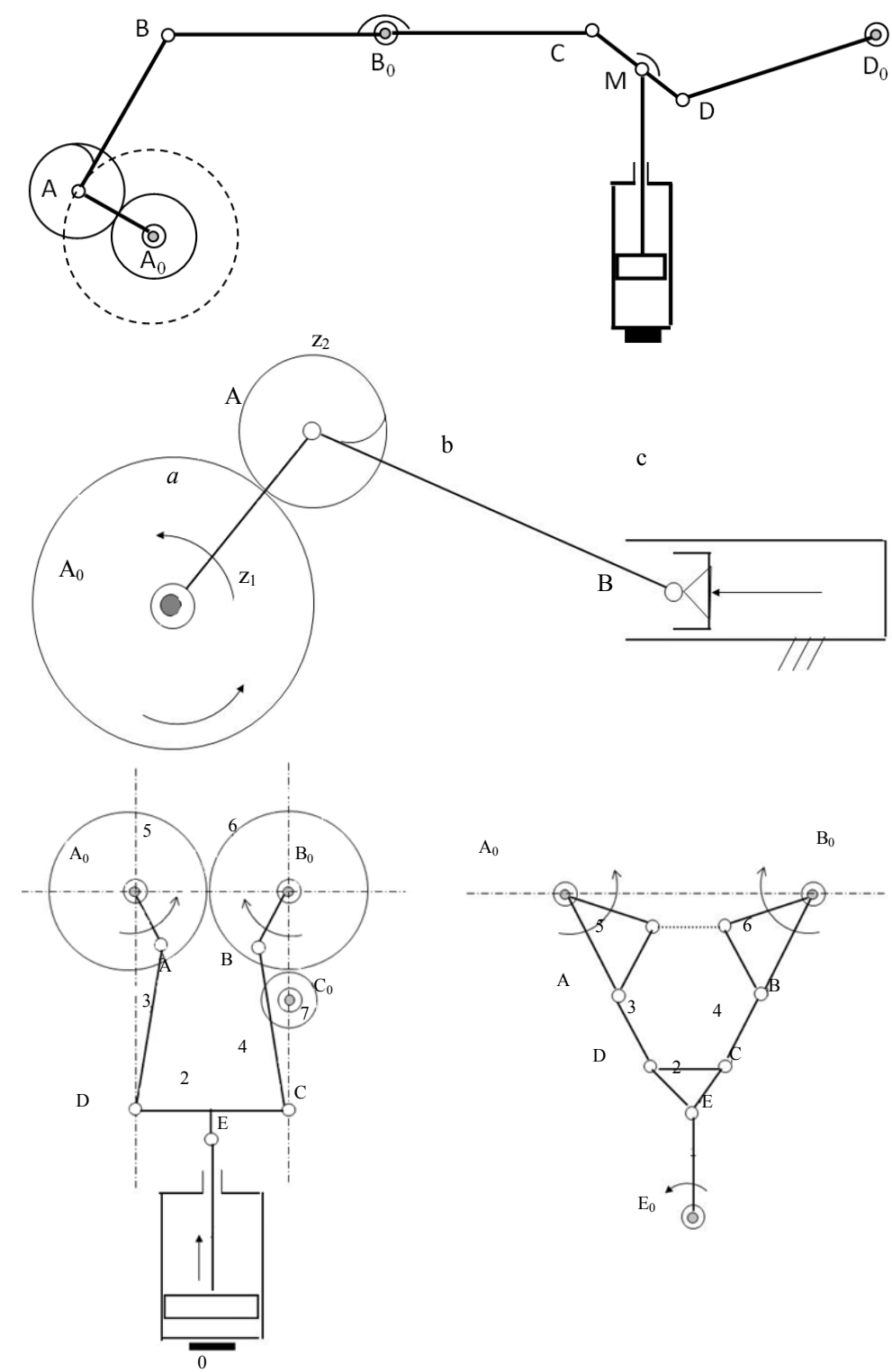

Fig. 1: Watt imagined a new mechanism, combining the crankshaft mechanism with a planetary gear with two gears 


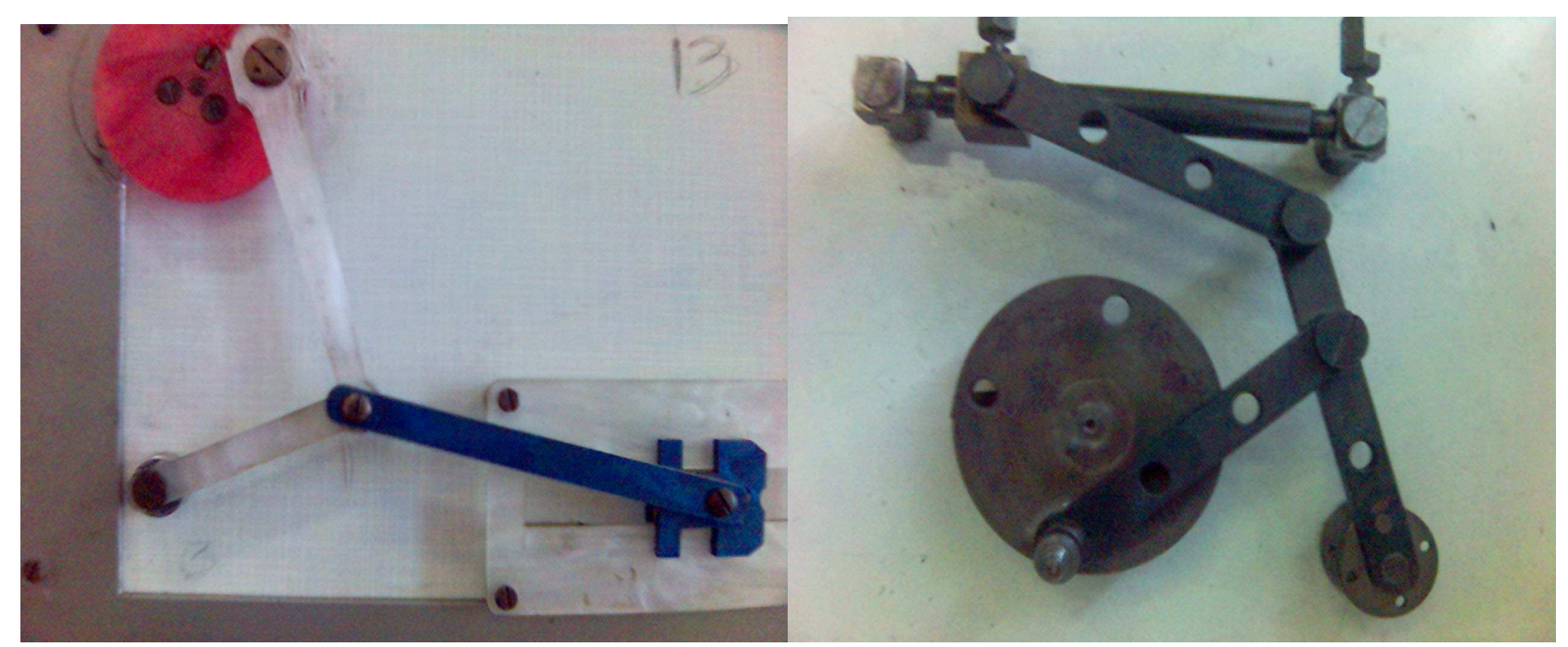

Fig. 2: The kinematic constructive schematic of a simple conveyor mechanism with various uses

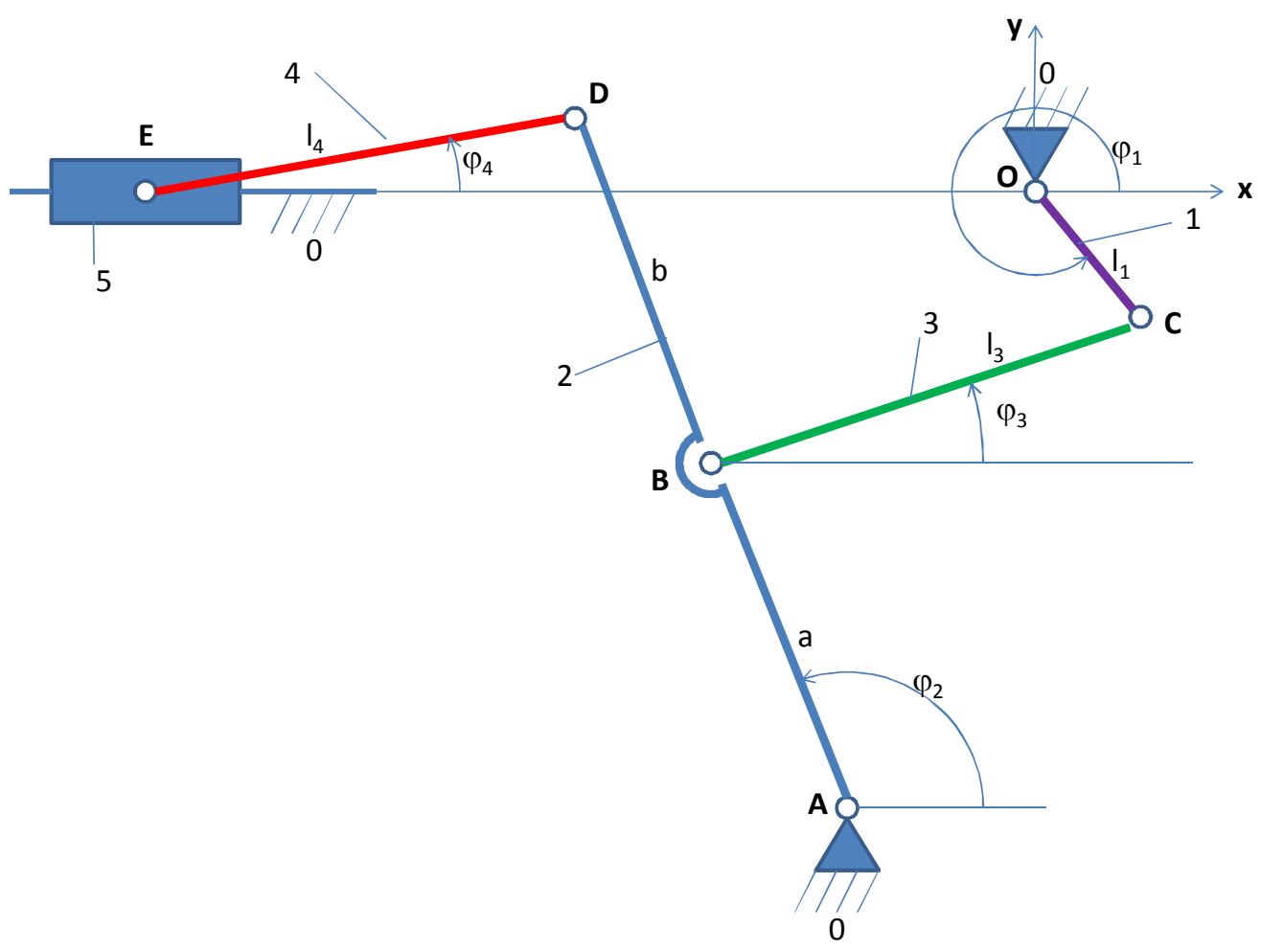

Fig. 3: The geometric-kinematic scheme of a planar manipulator

\section{Materials and Methods}

Being a simple, common manipulator, he is also a good teaching example, much used in the student courses of mechanics, mechanisms, robotics-mechatronics (Antonescu and Petrescu, 1985; 1989; Antonescu et al., 1985a-b; 1986; 1987; 1988; 1994; 1997; 2000a; 2000b; 2001; Aversa et al., 2017a-e; 2016a-o; Berto et al., 2016ad; Cao et al., 2013; Dong et al., 2013; Comanescu, 2010; Franklin, 1930; He et al., 2013; Lee, 2013; Lin et al., 2013; Liu et al., 2013; Mirsayar et al., 2017; Padula and Perdereau, 2013; Perumaal and Jawahar, 2013; Petrescu, 
2011; 2015a-b; Petrescu and Petrescu, 1995a-b; 1997a-c; 2000a-b; 2002a-b; 2003; 2005a-e; 2011; 2012a-b; 2013a-b; 2016a-c; Petrescu et al., 2009; 2016; 2017a-1).

That is why we want to present in this study in a concise way the geometry and the kinematics of this mechanism. There will be a constructive and one kinematic scheme. The mechanism consists of a crank (a motor element 1), an RRR dyad composed of elements 2 and 3 and an RRT dyad formed by kinematic elements 4 and 5. The motor element 1 has a complete rotation (360 degrees) being the single driving feature of the entire mechanism.

The element 3 is a bar that links the engine element 1 to the rocker element 2. From the rocker element 2, the movement is forwarded through the rod 4 to the final execution member 5 , which is a slider (patina), having the role of oscillating linearly (it can also be a piston in a cylinder).

The mechanism can also be used by changing the driving element to the driven one so as to become a motor mechanism with the leading element 5 and when the rotation element 1 to become a final driven element. Thus it can be used as a mechanism for producing the movement and transmitting it with the conversion from the rotation to translation movement. We intend to present this mechanism, in the present paper, when it functions as a manipulator, having the motor element 1 and the final element, the execution element, the patina 5. Special emphasis will be placed on the kinematics of the mechanism, studied on elements, but also on structural groups. Obviously there will be presented and some applications of the mechanism.
For the crank (element 1) of the mechanism the calculations are started with the relational system 1 :

$$
\left\{\begin{array}{l}
x_{C}=x_{O}+l_{1} \cdot \cos \phi_{1} \\
y_{C}=y_{O}+l_{1} \cdot \sin \phi_{1}
\end{array}\right.
$$

Mechatronic Module 3R (RRR) calculations are performed with the system relationships 2 obtained from Fig. 4, corresponding to module 3R:

$$
\left\{\begin{array}{l}
e=x_{C}-x_{A} \\
f=y_{C}-y_{A} \\
l=\sqrt{e^{2}+f^{2}} \\
\cos \phi=\frac{e}{l} \\
\sin \phi=\frac{f}{l} \\
\phi=\arccos (\cos \phi) \cdot \operatorname{sign}(\sin \phi) \\
\cos A=\frac{l^{2}+a^{2}-l_{3}^{2}}{2 a \cdot l} \\
\cos C=\frac{l^{2}+l_{3}^{2}-a^{2}}{2 l \cdot l_{3}} \\
A=\arccos (\cos A) \\
C=\arccos (\cos C) \\
\phi_{2}=\phi+A \\
\phi_{3}=\phi-C \\
x_{D}=x_{A}+l_{2} \cdot \cos \phi_{2} \\
y_{D}=y_{A}+l_{2} \cdot \sin \phi_{2}
\end{array}\right.
$$

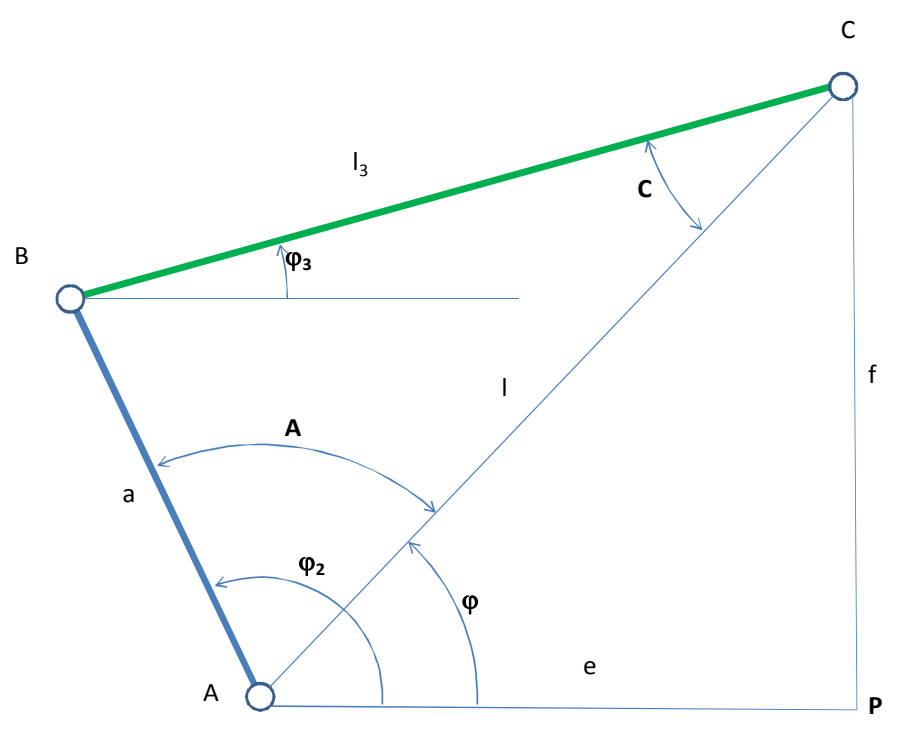

Fig. 4: Geometry and kinematics of 3R mechatronic module 
Module 3R was also shown on other occasions, it being made up of two planar relative elements, joined by a flat rotation coupler, a $\mathrm{C} 5$ coupler (noted with $\mathrm{B}$ ).

The module may still have two potential couplers, noted here with $\mathrm{A}$ and $\mathrm{C}$.

We know the lengths of the two bars of the mechatronic module, denoted by $l_{3}$ and a, as well as the positions of the kinematic couplings $\mathrm{C}$ and $\mathrm{A}$ and the positional angles of the mechatronic module must be determined, Fi2 and Fi3.

All calculations are executed using the relationships in system 2 .

\section{Results}

Follows the kinematic calculations for the RRT mechatronic module, having two rotation and one translational couplers (3).

$$
\begin{aligned}
& \left\{\begin{array}{l}
x_{D}=x_{E}+l_{4} \cdot \cos \phi_{4} \\
y_{D}=y_{E}+l_{4} \cdot \sin \phi_{4}
\end{array}=>\left\{\begin{array}{l}
x_{D}-x_{E}=l_{4} \cdot \cos \phi_{4} \\
y_{D}-y_{E}=l_{4} \cdot \sin \phi_{4}
\end{array}\right.\right. \\
& \left(x_{D}-x_{E}\right)^{2}+\left(y_{D}-y_{E}\right)^{2}=l_{4}^{2}=> \\
& \Rightarrow\left(x_{D}-x_{E}\right)^{2}=l_{4}^{2}-\left(y_{D}-y_{E}\right)^{2} \Rightarrow x_{\mathrm{E}} \\
& \int x_{E}=x_{D}-\sqrt{l_{4}^{2}-\left(y_{D}-y_{E}\right)^{2}} \\
& \cos \phi_{4}=\frac{x_{D}-x_{E}}{l_{4}} \\
& \sin \phi_{4}=\frac{y_{D}-y_{E}}{l_{4}} \\
& \phi_{4}=\arccos \left(\cos \phi_{4}\right) \cdot \operatorname{semn}\left(\sin \phi_{4}\right)
\end{aligned}
$$

At the end, four results are tabulated: $\varphi_{2} ; \varphi_{3} ; \varphi_{4} ; x_{E}$, calculated according to the input variable FI1.

\section{Discussion}

There will be a constructive and one kinematic scheme. The mechanism consists of a crank (a motor element 1), an RRR dyad composed of elements 2 and 3 and an RRT dyad formed by kinematic elements 4 and 5 .

The motor element 1 has a complete rotation (360 degrees) being the single driving feature of the entire mechanism. The element 3 is a bar that links the engine element 1 to the rocker element 2 . From the rocker element 2, the movement is forwarded through the rod 4 to the final execution member 5 , which is a slider (patina), having the role of oscillating linearly (it can also be a piston in a cylinder).

\section{Conclusion}

The mechanism can also be used by changing the driving element to the driven one so as to become a motor mechanism with the leading element 5 and when the rotation element 1 to become a final driven element.
Thus it can be used as a mechanism for producing the movement and transmitting it with the conversion from the rotation to translation movement. We intend to present this mechanism, in the present paper, when it functions as a manipulator, having the motor element 1 and the final element, the execution element, the patina 5 .

Special emphasis will be placed on the kinematics of the mechanism, studied on elements, but also on structural groups. Obviously there will be presented and some applications of the mechanism.

\section{Acknowledgment}

This text was acknowledged and appreciated by Dr. Veturia CHIROIU Honorific member of Technical Sciences Academy of Romania (ASTR) PhD supervisor in Mechanical Engineering.

\section{Funding Information}

Research contract: 1-Research contract: Contract number 36-5-4D/1986 from 24IV1985, beneficiary CNST RO (Romanian National Center for Science and Technology) Improving dynamic mechanisms.

2-Contract research integration. 19-91-3 from 29.03.1991; Beneficiary: MIS; TOPIC: Research on designing mechanisms with bars, cams and gears, with application in industrial robots.

3-Contract research. GR 69/10.05.2007: NURC in 2762; theme 8: Dynamic analysis of mechanisms and manipulators with bars and gears.

4-Labor contract, no. 35/22.01.2013, the UPB, "Stand for reading performance parameters of kinematics and dynamic mechanisms, using inductive and incremental encoders, to a Mitsubishi Mechatronic System" "PN-IIIN-CI-2012-1-0389".

All these matters are copyrighted! Copyrights: 394qodGnhhtej, from 17-02-2010 13:42:18; 463vpstuCGsiy, from 20-03-2010 12:45:30; 631sqfsgquutm, from 24-05-2010 16:15:22; 933CrDztEfqow, from 07-01-2011 13:37:52.

\section{Author's Contributions}

This section should state the contributions made by each author in the preparation, development and publication of this manuscript.

\section{Ethics}

Authors should address any ethical issues that may arise after the publication of this manuscript. 


\section{References}

Antonescu, P. and F. Petrescu, 1985. An analytical method of synthesis of cam mechanism and flat stick. Proceedings of the 4th International Symposium on Theory and Practice of Mechanisms, (TPM' 85), Bucharest.

Antonescu, P. and F. Petrescu, 1989. Contributions to Kinetoelastodynamic analysis of distribution mechanisms. Bucharest.

Antonescu, P., M. Oprean and F. Petrescu, 1985a. Contributions to the synthesis of oscillating cam mechanism and oscillating flat stick. Proceedings of the 4th International Symposium on Theory and Practice of Mechanisms, (TPM' 85), Bucharest.

Antonescu, P., M. Oprean and F. Petrescu, 1985b. At the projection of the oscillate cams, there are mechanisms and distribution variables. Proceedings of the 5th Conference of Engines, Automobiles, Tractors and Agricultural Machines, (TAM' 85), Brasov.

Antonescu, P., M. Oprean and F. Petrescu, 1986. Projection of the profile of the rotating camshaft acting on the oscillating plate with disengagement. Proceedings of the 3rd National Computer-Aided Design Symposium in the Field of Machinery and Machinery Organs, (FMM' 86), Brasov.

Antonescu, P., M. Oprean and F. Petrescu, 1987. Dynamic analysis of the cam distribution mechanisms. Proceedings of the 7th National Symposium of Industrial Robots and Space Mechanisms, (RSM' 87), Bucharest.

Antonescu, P., M. Oprean and F. Petrescu, 1988. Analytical synthesis of Kurz profile, rotating the flat cam. Mach. Build. Rev.

Antonescu, P., F. Petrescu and O. Antonescu, 1994. Contributions to the synthesis of the rotating cam mechanism and the tip of the balancing tip. Brasov.

Antonescu, P., F. Petrescu and D. Antonescu, 1997. Geometrical synthesis of the rotary cam and balance tappet mechanism. Bucharest, 3: 23-23.

Antonescu, P., F. Petrescu and O. Antonescu, 2000a. Contributions to the synthesis of the rotary disc-cam profile. Proceedings of the 8th International Conference on the Theory of Machines and Mechanisms, (TMM' 00), Liberec, Czech Republic, pp: 51-56.

Antonescu, P., F. Petrescu and O. Antonescu, 2000b. Synthesis of the rotary cam profile with balance follower. Proceedings of the 8th Symposium on Mechanisms and Mechanical Transmissions, (MMT' 00), Timişoara, pp: 39-44.

Antonescu, P., F. Petrescu and O. Antonescu, 2001. Contributions to the synthesis of mechanisms with rotary disc-cam. Pro 8th IFToMM International Symposium on Theory of Machines and Mechanisms, (TMM' 01), Bucharest, ROMANIA, pp: 31-36.
Aversa, R., R.V.V. Petrescu, A. Apicella and F.I.T. Petrescu, 2017a. Nano-diamond hybrid materials for structural biomedical application. Am. J. Biochem. Biotechnol.

Aversa, R., R.V. Petrescu, B. Akash, R.B. Bucinell and J.M. Corchado et al., 2017b. Kinematics and forces to a new model forging manipulator. Am. J. Applied Sci., 14: 60-80.

Aversa, R., R.V. Petrescu, A. Apicella, F.I.T. Petrescu and J.K. Calautit et al., 2017c. Something about the $\mathrm{V}$ engines design. Am. J. Applied Sci., 14: 34-52.

Aversa, R., D. Parcesepe, R.V.V. Petrescu, F. Berto and G. Chen et al., 2017d. Process ability of bulk metallic glasses. Am. J. Applied Sci., 14: 294-301.

Aversa, R., R.V.V. Petrescu, B. Akash, R.B. Bucinell and J.M. Corchado et al., 2017e. Something about the balancing of thermal motors. Am. J. Eng. Applied Sci.

Aversa, R., F.I.T. Petrescu, R.V. Petrescu and A. Apicella, 2016a. Biomimetic FEA bone modeling for customized hybrid biological prostheses development. Am. J. Applied Sci., 13: 1060-1067. DOI: 10.3844/ajassp.2016.1060.1067

Aversa, R., D. Parcesepe, R.V. Petrescu, G. Chen and F.I.T. Petrescu et al., 2016b. Glassy amorphous metal injection molded induced morphological defects. Am. J. Applied Sci., 13: 1476-1482.

Aversa, R., R.V. Petrescu, F.I.T. Petrescu and A. Apicella, 2016c. Smart-factory: Optimization and process control of composite centrifuged pipes. Am. J. Applied Sci., 13: 1330-1341.

Aversa, R., F. Tamburrino, R.V. Petrescu, F.I.T. Petrescu and M. Artur et al., 2016d. Biomechanically inspired shape memory effect machines driven by muscle like acting NiTi alloys. Am. J. Applied Sci., 13: 1264-1271.

Aversa, R., E.M. Buzea, R.V. Petrescu, A. Apicella and M. Neacsa et al., 2016e. Present a mechatronic system having able to determine the concentration of carotenoids. Am. J. Eng. Applied Sci., 9: 1106-1111.

Aversa, R., R.V. Petrescu, R. Sorrentino, F.I.T. Petrescu and A. Apicella, 2016f. Hybrid ceramo-polymeric nanocomposite for biomimetic scaffolds design and preparation. Am. J. Eng. Applied Sci., 9: 1096-1105.

Aversa, R., V. Perrotta, R.V. Petrescu, C. Misiano and F.I.T. Petrescu et al., 2016g. From structural colors to super-hydrophobicity and achromatic transparent protective coatings: Ion plating plasma assisted $\mathrm{TiO}_{2}$ and $\mathrm{SiO}_{2}$ nano-film deposition. Am. J. Eng. Applied Sci., 9: 1037-1045.

Aversa, R., R.V. Petrescu, F.I.T. Petrescu and A. Apicella, 2016h. Biomimetic and evolutionary design driven innovation in sustainable products development. Am. J. Eng. Applied Sci., 9: 1027-1036. 
Aversa, R., R.V. Petrescu, A. Apicella and F.I.T. Petrescu, 2016i. Mitochondria are naturally micro robots - a review. Am. J. Eng. Applied Sci., 9: 991-1002.

Aversa, R., R.V. Petrescu, A. Apicella and F.I.T. Petrescu, 2016j. We are addicted to vitamins $\mathrm{C}$ and E-A review. Am. J. Eng. Applied Sci., 9: 1003-1018.

Aversa, R., R.V. Petrescu, A. Apicella and F.I.T. Petrescu, 2016k. Physiologic human fluids and swelling behavior of hydrophilic biocompatible hybrid ceramo-polymeric materials. Am. J. Eng. Applied Sci., 9: 962-972.

Aversa, R., R.V. Petrescu, A. Apicella and F.I.T. Petrescu, 20161. One can slow down the aging through antioxidants. Am. J. Eng. Applied Sci., 9: 1112-1126.

Aversa, R., R.V. Petrescu, A. Apicella and F.I.T. Petrescu, 2016m. About homeopathy or «Similia Similibus Curentur 》. Am. J. Eng. Applied Sci., 9: 1164-1172.

Aversa, R., R.V. Petrescu, A. Apicella and F.I.T. Petrescu, 2016n. The basic elements of life's. Am. J. Eng. Applied Sci., 9: 1189-1197.

Aversa, R., F.I.T. Petrescu, R.V. Petrescu and A. Apicella, 2016o. Flexible stem trabecular prostheses. Am. J. Eng. Applied Sci., 9: 1213-1221.

Berto, F., R.V.V. Petrescu and F.I.T. Petrescu, 2016a. A review of recent results on 3D effects. Am. J. Eng. Applied Sci., 9: 1247-1260.

Berto, F., R.V.V. Petrescu and F.I.T. Petrescu, 2016 b. Three-dimensional in bonded joints: A short review. Am. J. Eng. Applied Sci., 9: 1261-1268.

Berto, F., A. Gagani, R.V.V. Petrescu and F.I.T. Petrescu, 2016c. Key-hole notches in isostatic graphite: A review of some recent data. Am. J. Eng. Applied Sci., 9: 1292-1300.

Berto, F., A. Gagani, R. Aversa, R.V.V. Petrescu and A. Apicella et al., 2016d. Multiaxial fatigue strength to notched specimens made of 40CrMoV13.9. Am. J. Eng. Applied Sci., 9: 1269-1291.

Cao, W., H. Ding, Z. Bin and C. Ziming, 2013. New structural representation and digital-analysis platform for symmetrical parallel mechanisms. Int. J. Adv. Robotic Sys. DOI: 10.5772/56380

Comanescu, A., 2010. Bazele modelarii mecanismelor. 1st Edn., E. Politeh. Press, Bucureşti, pp: 274.

Dong, H., N. Giakoumidis, N. Figueroa and N. Mavridis, 2013. Approaching behaviour monitor and vibration indication in developing a General Moving Object Alarm System (GMOAS). Int. J. Adv. Robotic Sys. DOI: $10.5772 / 56586$

Franklin, D.J., 1930. Ingenious mechanisms for designers and inventors. Industrial Press Publisher.

He, B., Z. Wang, Q. Li, H. Xie and R. Shen, 2013. An analytic method for the kinematics and dynamics of a multiple-backbone continuum robot. IJARS. DOI: $10.5772 / 54051$
Lee, B.J., 2013. Geometrical derivation of differential kinematics to calibrate model parameters of flexible manipulator. Int. J. Adv. Robotic Sys. DOI: $10.5772 / 55592$

Lin, W., B. Li, X. Yang and D. Zhang, 2013. Modelling and control of inverse dynamics for a 5-DOF parallel kinematic polishing machine. Int. J. Adv. Robotic Sys. DOI: 10.5772/54966

Liu, H., W. Zhou, X. Lai and S. Zhu, 2013. An efficient inverse kinematic algorithm for a PUMA560structured robot manipulator. IJARS. DOI: $10.5772 / 56403$

Mirsayar, M.M., V.A. Joneidi, R.V.V. Petrescu, F.I.T. Petrescu and F. Berto, 2017. Extended MTSN criterion for fracture analysis of soda lime glass. Eng. Fracture Mechanics, 178: 50-59. DOI: 10.1016/j.engfracmech.2017.04.018

Padula, F. and V. Perdereau, 2013. An on-line path planner for industrial manipulators. Int. J. Adv. Robotic Sys. DOI: 10.5772/55063

Perumaal, S. and N. Jawahar, 2013. Automated trajectory planner of industrial robot for pick-andplace task. IJARS. DOI: 10.5772/53940

Petrescu, F. and R. Petrescu, 1995a. Contributions to optimization of the polynomial motion laws of the stick from the internal combustion engine distribution mechanism. Bucharest. 1: 249-256.

Petrescu, F. and R. Petrescu, 1995b. Contributions to the synthesis of internal combustion engine distribution mechanisms. Bucharest. 1: 257-264.

Petrescu, F. and R. Petrescu, 1997a. Dynamics of cam mechanisms (exemplified on the classic distribution mechanism). Bucharest. 3: 353-358.

Petrescu, F. and R. Petrescu, 1997b. Contributions to the synthesis of the distribution mechanisms of internal combustion engines with the Cartesian coordinate method. Bucharest. 3: 359-364.

Petrescu, F. and R. Petrescu, 1997c. Contributions to maximizing polynomial laws for the active stroke of the internal combustion engine distribution mechanism. Bucharest. 3: 365-370.

Petrescu, F. and R. Petrescu, 2000a. Synthesis of distribution mechanisms by the rectangular (cartesian) coordinate method. Proceedings of the 8th National Conference with International Participation (CIP '00), Craiova, Romania, pp: 297-302.

Petrescu, F. and R. Petrescu, 2000b. The design (synthesis) of cams using the polar coordinate method (triangle method). Proceedings of the 8th National Conference with International Participation (CIP '00), Craiova, Romania, pp: 291-296.

Petrescu, F. and R. Petrescu, 2002a. Motion laws for cams. Proceedings of the International Computer Assisted Design, National Participation Symposium, (SNP '02), Braşov, pp: 321-326. 
Petrescu, F. and R. Petrescu, 2002b. Camshaft dynamics elements. Proceedings of the International Computer Assisted Design, National Participation Symposium, (SNP '02), Braşov, pp: 327-332.

Petrescu, F. and R. Petrescu, 2003. Some elements regarding the improvement of the engine design. Proceedings of the National Symposium, Descriptive Geometry, Technical Graphics and Design, (GTD '03), Braşov, pp: 353-358.

Petrescu, F. and R. Petrescu, 2005a. The cam design for a better efficiency. Proceedings of the International Conference on Engineering Graphics and Design, (EGD' 05), Bucharest, pp: 245-248.

Petrescu, F. and R. Petrescu, 2005b. Contributions at the dynamics of cams. Proceedings of the Ninth IFToMM International Symposium on Theory of Machines and Mechanisms, (TMM' 05), Bucharest, Romania, pp: 123-128.

Petrescu, F. and R. Petrescu, 2005c. Determining the dynamic efficiency of cams. Proceedings of the Ninth IFToMM International Symposium on Theory of Machines and Mechanisms, (TMM' 05), Bucharest, Romania, pp: 129-134.

Petrescu, F. and R. Petrescu, 2005d. An original internal combustion engine. Proceedings of the Ninth IFToMM International Symposium on Theory of Machines and Mechanisms, (TMM' 05), Bucharest, Romania, pp: 135-140.

Petrescu, F. and R. Petrescu, 2005e. Determining the mechanical efficiency of Otto engine's mechanism. Proceedings of the Ninth IFToMM International Symposium on Theory of Machines and Mechanisms, (TMM 05), Bucharest, Romania, pp: 141-146.

Petrescu, F.I. and R.V. Petrescu, 2011. Mechanical Systems, Serial and Parallel (Romanian). 1st Edn., LULU Publisher, London, UK, pp: 124.

Petrescu, F.I. and R.V. Petrescu, 2012a. Kinematics of the planar quadrilateral mechanism. Engevista, 14: 345-348.

Petrescu, F.I. and R.V. Petrescu, 2012b MecatronicaSisteme Seriale si paralele. 1st Edn., Create Space Publisher, USA, pp: 128.

Petrescu, F.I. and R.V. Petrescu, 2013a. Cinematics of the 3R Dyad. Engevista, 15: 118-124.

Petrescu, F.I. and R.V. Petrescu, 2013b. Forces and efficiency of cams. Int. Rev. Mechanical Eng.

Petrescu, F.I. and R.V. Petrescu, 2016a. Parallel moving mechanical systems kinematics. ENGEVISTA, 18: 455-491.

Petrescu, F.I. and R.V. Petrescu, 2016b. Direct and inverse kinematics to the anthropomorphic robots. ENGEVISTA, 18: 109-124.

Petrescu, F.I. and R.V. Petrescu, 2016c. Dynamic cinematic to a structure $2 \mathrm{R}$. Revista Geintec-Gestao Inovacao E Tecnologias, 6: 3143-3154.
Petrescu, R.V., R. Aversa, B. Akash, R. Bucinell and J. Corchado et al., 2017a. Yield at thermal engines internal combustion. Am. J. Eng. Applied Sci., 10: 243-251.

Petrescu, R.V., R. Aversa, B. Akash, B. Ronald and J. Corchado et al., 2017b. Velocities and accelerations at the 3R mechatronic systems. Am. J. Eng. Applied Sci., 10: 252-263.

Petrescu, R.V., R. Aversa, B. Akash, R. Bucinell and J. Corchado et al., 2017c. Anthropomorphic solid structures n-r kinematics. Am. J. Eng. Applied Sci., 10: 279-291.

Petrescu, R.V., R. Aversa, B. Akash, R. Bucinell and J. Corchado et al., 2017d. Inverse kinematics at the anthropomorphic robots, by a trigonometric method. Am. J. Eng. Applied Sci., 10: 394-411.

Petrescu, R.V., R. Aversa, B. Akash, R. Bucinell and J. Corchado et al., 2017e. Forces at internal combustion engines. Am. J. Eng. Applied Sci., 10: 382-393.

Petrescu, R.V., R. Aversa, B. Akash, R. Bucinell and J. Corchado et al., 2017f. Gears-Part I. Am. J. Eng. Applied Sci., 10: 457-472.

Petrescu, R.V., R. Aversa, B. Akash, R. Bucinell and J. Corchado et al., 2017g. Gears-part II. Am. J. Eng. Applied Sci., 10: 473-483.

Petrescu, R.V., R. Aversa, B. Akash, R. Bucinell and J. Corchado et al., 2017h. Cam-gears forces, velocities, powers and efficiency. Am. J. Eng. Applied Sci., 10: 491-505.

Petrescu, R.V., R. Aversa, B. Akash, R. Bucinell and J. Corchado et al., 2017i. Dynamics of mechanisms with cams illustrated in the classical distribution. Am. J. Eng. Applied Sci., 10: 551-567.

Petrescu, R.V., R. Aversa, B. Akash, R. Bucinell and J. Corchado et al., 2017j. Testing by non-destructive control. Am. J. Eng. Applied Sci., 10: 568-583.

Petrescu, R.V., R. Aversa, A. Apicella and F.I.T. Petrescu, 2017k. Transportation engineering. Am. J. Eng. Applied Sci., 10: 685-702.

Petrescu, R.V., R. Aversa, S. Kozaitis, A. Apicella and F.I.T. Petrescu, 20171. The quality of transport and environmental protection, part I. Am. J. Eng. Applied Sci., 10: 738-755.

Petrescu, R.V., R. Aversa, A. Apicella and F.I. Petrescu, 2016. Future medicine services robotics. Am. J. Eng. Applied Sci., 9: 1062-1087.

Petrescu, F.I., B. Grecu, A. Comanescu and R.V. Petrescu, 2009. Some mechanical design elements. Proceeding of the International Conference on Computational Mechanics and Virtual Engineering, (MVE’ 09), Braşov, pp: 520-525.

Petrescu, F.I., 2011. Teoria Mecanismelor si a Masinilor: Curs Si Aplicatii. 1st Edn., CreateSpace Independent Publishing Platform. ISBN-10: 1468015826. pp: 432. 
Relly Victoria Virgil Petrescu et al. / Journal of Mechatronics and Robotics 2017, 1 (2): 118.126

10.3844/jmrsp.2017.118.126

Petrescu, F.I.T., 2015a. Geometrical synthesis of the distribution mechanisms. Am. J. Eng. Applied Sci., 8: 63-81.

Petrescu, F.I.T., 2015b. Machine motion equations at the internal combustion heat engines. Am. J. Eng. Applied Sci., 8: 127-137.

\section{Source of Figures:}

All Figures were drawn by the corresponding author. 